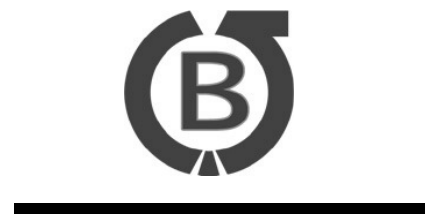

FACULTY OF MANAGEMENT \& FINANCE UNIVERSITY OF COLOMBO
Colombo

Business

Journal

INTERNATIONAL JOURNAL OF

THEORY \& PRACTICE

Vol. 08, No. 02, December, 2017

\title{
The Impact of Earnings Quality on the Stock Returns of Listed Manufacturing Companies in the Colombo Stock Exchange
}

\author{
M. R. P. Wijesinghe ${ }^{a}$, Sampath Kehelwalatenna ${ }^{\text {b1 }}$ \\ ${ }^{a}$ Department of Finance, University of Kelaniya, Sri Lanka, \\ ${ }^{b}$ Department of Accounting, University of Colombo, Sri Lanka
}

\begin{abstract}
The earnings of a company is a very important indicator of firm performance, since it communicates information about the value creating ability of the company to its stakeholders. It is also considered a determinant of the stock market performance of the company. However, the possibility for managers to manipulate the true earnings of a company erodes the importance of using recorded earnings information in financial statements for decision making. Earnings quality could be measured using different proxy measures, varying from traditional accrual based measures to recent real earnings based measures. The earnings quality literature contains a plethora of evidence on the impact of earnings quality measured through accrual based measures on stock returns but it does not have as much evidence on the same impact where earnings quality is measured through real earnings. Further, the literature does not have a comparative study on how different earnings quality measures provide different results in the estimation of the impact of earnings quality on stock returns. Empirical evidence on the same relationship using data from the Sri Lankan context is virtually absent in the extant literature. In this milieu, the present study examines the impact of earnings quality measured through both accrual based measures and real earnings measures on stock returns of listed manufacturing companies in Sri Lanka during the period of 2010 to 2015. The findings of the study reveal that there is no significant positive impact of earnings quality on stock returns of the firms selected for the study. This suggests that earnings quality information of the selected firms fails to win investor trust when investors make their decisions. Perhaps this may be due to the fact that
\end{abstract}

1Corresponding Author: sampath.kehelwalatenna@gmail.com

iD https://orcid.org/0000-0001-5702-2364 
earnings manipulation is evident in the Sri Lankan context. Further, the study reveals that there is no inconsistency when measuring earnings quality through competing measurements.

Keywords: Earnings Quality, Earnings Management, Stock Returns, Colombo Stock Exchange

\section{Background of the Study}

Financial statements are one of the reliable sources that stakeholders can access in order to obtain information regarding companies, and still remain the most important source of externally feasible information on companies (Meyer, 2007). Rational investors refer to financial statements before making economic decisions and there are many accounting variables that investors might refer to in their decision making. As per Ball and Brown (1968), investors consider earnings of the companies in particular, as it provides information with which to predict stock prices in the future. Therefore, it can be argued that if such information is not relevant, or rather if stakeholders are not using such information to make their economic decisions, the whole purpose of financial reporting becomes worthless.

Furthermore, the financial reporting standards of a country play a vital role in enhancing the relevance, reliability and comparability of the reported earnings. However, the fact is that reported earnings, which are based on standards, do not reflect the true earnings of the companies, which are based on quality. This is because managers may be involved in earnings manipulations in order to earn bonuses, obtain compensation and enhance their corporate image (Burgstahler \& Dichev, 1997; Noronha, Zeng, \& Vinten, 2008; Schipper, 1989). In addition, there are many other reasons why and how managers manipulate, such as capital market pressure, managerial incentives, political connections, building credibility with the capital market, maintaining or increasing stock prices, improving the external reputation of the management team, to convey future growth prospects and unrealistic forecasting of revenues. Therefore, the true earnings of the business are not visible through financial statements, due to the large number of accounting estimations, judgments and the greater involvement of management even after compliance with the accounting standards, all of which may sabotage the quality of earnings. Due to these reasons, it is questionable whether reported earnings reflect the true quality of the earnings of companies.

It is apparent that when earnings management is absent and when companies are not manipulating earnings, the quality of the earnings is high. However, extant 
literature reveals that scholars have used different measurements to denote the quality of the earnings. Most of the initial proxies have taken accruals as the foundation for calculating the earnings quality. The most common method used in the early stages of earnings management literature is Jones' (1991) Model which uses discretionary accruals to indicate the quality of earnings. This model was subsequently modified by Dechow, Sloan, and Sweeney (1995) and called the Modified Jones' Model, and it was modified by addressing the weaknesses in the original model. Subsequently, Penman and Zhang (2002) introduced the C - score which measures the effect of the application of conservative accounting on the balance sheet by the level of estimated reserves that are created by the conservatism relative to the net operating assets. Barton and Simko (2002) have measured the quality of the earnings by the ratio of the initial balance of net operating assets relative to sales. Further, Leuz, Nanda, and Wysocki (2003) introduced the ratio of the standard deviation of operating earnings to the standard deviation of cash from operations, to measure the earnings quality.

However, prior literature on earnings quality has highlighted the importance of using real activities as a proxy to measure the earnings quality as a different way to measure earnings quality, denoted by real activities of managers and real actions to manage earnings (Roychowdhury, 2006). In the same vein, studies on earnings quality and stock returns are limited and have not considered the importance of real earnings management as a measure to detect earnings quality. Given the importance of real earnings management as a measure to detect earnings management (Healy \& Wahlen, 1999; Ewert \& Wagenhofer, 2005; Roychowdhury, 2006; Cohen, Dey, \& Lys, 2008; Guo, Huang, Zhang, \& Zhou, 2014; Kighir, Omar, \& Mohamed, 2014; Gunny, 2010), it is vital as well as reasonable to investigate the relationship between earnings quality measured by real earnings management and stock returns.

Furthermore, previous studies on earnings quality and stock returns have investigated the relationship between them for the share market as a whole, without considering the nature of the particular industry involved. The findings of Abdelghany (2005), Lyimo (2014), and Wasiuzzaman, Sahafzadeh, and Nejad (2015) indicate that earnings management is different across industries. Therefore, a measurement applicable for one industry might not be applicable for another industry when measuring earnings quality. At the same time, prior studies have not combined the accrual approach, the real earnings management approach and other measurements in one study. Combining them in a single study is important to identify the compatibility of the earnings management proxies. In addition to that, 
Burgstahler and Dichev (1997) highlight the importance of investigating the earnings quality phenomenon in the manufacturing sector since this requires huge investments in current assets. As per Halabi and Abbadi (2014), earnings quality of both manufacturing and non-manufacturing sector companies should be investigated and analysed. Roychowdhury (2006) in his conclusion emphasised that real activities manipulation is more evident in manufacturing industries.

As discussed thus far, it is apparent that earnings quality literature does not contain studies that investigate the impact of earnings quality on stock returns using the real earnings management approach. Further, the studies conducted using other measures to denote earnings quality cannot be applied to Sri Lanka as the context is different. At the same time, previous studies conducted using other measures to denote earnings quality have not considered the nature of the industry as they should, since earnings quality measurements are different across industries. Therefore, the present study attempts to investigate the impact of earnings quality measured by real earnings management on stock returns of listed manufacturing sector companies in Sri Lanka. Further, the study examines whether the measures identified in the study as real, accrual and other measures do provide similar predictability of stock returns of the selected firms of the study.

The remainder of the paper is organised as follows. The next section reviews the literature relevant to the study. This will be followed by an explanation of the methodology. Then results of the study will be presented and discussed. The final section will present conclusions and directions for further studies.

\section{Literature Review}

"In the investment management industry, it is common for investors, analysts and portfolio managers to focus on a firm's bottom-line reported earnings as an indicator of a firm's future performance" (Basilico, 2014, p. 4). Now, earnings of the entity is considered as one of the most important indicators of firm performance, while previously the most important indicator was the cash flow of the entity. Hence, managers always try to beat, or, at least meet their earnings target. As per K. Chan, Chan, Jegadeesh, and Lakonishok (2006) managers, investors and security analysts place a great deal of importance on a firm's reported earnings. This is because earnings information is available to them for their economic decisions, and managers are keen to see the growth of earnings since their compensations are generally driven by it. As per Dechow (1994), an earnings figure is the summarised 
measure of performance of the entity which provides information to both creditors and investors alike.

Given the importance of earnings, scholars have investigated whether actual earnings are important for decision makers. Ball and Brown (1968) were the first researchers to link accounting income numbers with the share price in order to quantify the outcome through real output. In the context of Sri Lanka, Menike and Prabath (2014) investigated the impact of dividend per share, earnings per share and book value per share on stock price at the Colombo Stock Exchange for 2008 to 2012 using 100 companies. In concluding the analysis, they identified that there is a significant impact from the above variables on share price, thus providing evidence that there is a significant relationship between earnings and stock returns. Based on these prior studies, the importance of earnings figures of companies can be judged together with how useful the earnings number is in predicting future earnings and share prices. However, as recorded earnings are subject to the manipulations of managers, the relationship between earnings and stock returns may sometimes be questionable. Further, there has been a growing concern about a firm's quality of earnings or the extent to which reported earnings reflect operating fundamentals (Chan et al., 2006) in accounting literature. This leads to the question whether earnings can be taken to relate to stock returns or not.

As cited in Kighir et al. (2014), Davidson et al. (1987) indicated that earnings management is a process of taking deliberate steps within the constraints of Generally Accepted Accounting Principles to bring about a desired level of reported earnings. Therefore, putting it simply, the concept of earnings quality reflects the operating fundamentals of the company, which in turn, represents the true portrait of the company. Braam, Nandy, Weitzel, and Lodh (2015) concluded that firms which are politically connected are more likely to engage in real earnings management than accrual based earnings management, even if it is more costly for the firms. Further, earnings management can be defined as deliberately manipulating operational activities in order to intervene in financial reporting and achieve managers' personal goals (Schipper, 1989). Burgstahler and Dichev (1997) found that managers often manipulate the real activities of corporations through cash flows from operating and working capital in order to engage in earnings management. By using a sample of 538 companies from 15 different industries, Wasiuzzaman et al. (2015) found that Malaysian firms are engaging in earnings management activities. In concluding the study, they posited that earnings management differs across industries. 
Given the background of earnings management efforts, it is vital to understand the meaning of earnings quality. As cited in Kamarudin and Ismail (2014), Yee (2006) states that earnings quality is based on the ability of reported earnings to quickly and precisely reveal a firm's fundamental earnings. In a separate stream of thinking, Revsine, Collins, and Johnson (2002) state that earnings are considered to be of a high quality when they are sustainable, while Bodie, Kane, and Marcus (2002) defined the quality of earnings as the extent to which we might expect the reported level of earnings to be sustained. Therefore, the quality of earnings should convey the true portrait of the business that enables stakeholders to take their economic decisions, and should reflect the future earnings or the share price. Numerous scholars have come up with different techniques to quantify earnings quality. The focus of this literature review now shifts to the different measures that can be used to quantify the earnings quality of companies.

Kighir et al. (2014) emphasised the importance of using real activities to detect earnings manipulations. Healy (1985) studied the phenomenon of earnings management using total accruals (scaled by lagged total assets) as a proxy for discretionary accruals. Hence, earnings management for the first time was measured by total accruals, as against specific component accruals used by prior researchers as a measure for earnings management. Jones (1991) focused on total accruals as the source of earnings management and has used discretionary accruals as a measure of managers' earnings manipulations during import relief investigations. The author concluded that managers decrease earnings through earnings management during import relief investigations. Sloan (1996) has investigated whether stock prices reflect information about future earnings contained in the accrual and cash flow components of current earnings. When concluding the study he argued that the accrual and cash components of earnings are both relevant to financial statement users, but the former is less reliable. Therefore, the accrual component of earnings is less persistent than the cash flow component.

The meaning of accruals is still evolving in the earnings quality literature and scholars have taken different proxies to measure accruals (Dechow, Ge, \& Schrand, 2010). For an example, Hribar and Collins (2002) calculated accruals by taking the difference between earnings and cash flows. Peasnell, Pope, and Young (2000) introduced an alternative model for estimating abnormal accruals known as the 'Margin Model' to mitigate the weaknesses associated with the use of the Jones' Model and the Modified Jones' Model when using cross-sectional data. Lyimo 
(2014) has used the difference between earnings and cash flow divided by the average assets in order to measure the quality of the earnings.

With these available measures, scholars are still developing ways in which they can measure the quality of earnings, since the extant measures have their own pros and cons. Thus, a result of a real earnings management approach in the literature is that earnings quality can be measured by minimising the disadvantages of other measures. In this regard, Roychowdhury (2006) has made a remarkable move to detect earnings management and it can be viewed as a paradigm shift in the earnings quality literature.

Yamchi, Salteh, and Nahandi (2013) investigated the relationship between the quality of earnings and stock return volatility in 79 companies listed on the Tehran Stock Exchange over the period of 2005 to 2010. In their study, they used three models to detect the earnings quality taken from Barton and Simko (2002), Leuz et al. (2003) and the model of Richardson, Sloan, Soliman and Tuna (2005). The findings of the study concluded that there is no significant relationship between earnings quality and stock return volatility. This is due to the lack of awareness within the investors regarding the earnings quality. Theoretically, however, the quality of earnings is important in describing returns alterations. By analysing the earnings quality with different variables including share price, a few past studies have identified that there is an impact from the industry in which it operates. As per Burgstahler and Dichev (1997), earnings management activities may be more prevalent in industries which require large investments in current assets. Wasiuzzaman et al. (2015) identified that earnings management differs across industries, and therefore one single measurement is not suitable for the market as a whole. Further, Halabi and Abbadi (2014) measured the impact of applying financial performance indicators on earnings management in manufacturing companies listed on the Amman Stock Exchange. They have recommended further studies in this area in manufacturing companies and non-manufacturing companies.

In conclusion, the recorded earnings of companies are important to their stakeholders since they provide information on the performance of the entities. Given the importance of earnings, scholars have established the relationship between earnings and stock returns in order to judge whether the outcome of an entity is reflected through the share price. However, as there are many avenues available for the entities to engage in earnings management, it is questionable whether the established relationship between earnings and stock return is valid. 
Against this backdrop, scholars have come up with the concept of earnings quality, and there are now numerous measures and models available to detect earnings management, each with its own pros and cons. However, there are only a limited number of studies on the relationship between earnings quality (measured through the accrual models and other measures) and stock returns, given the fact that earnings quality reflects the true portrait of the entity's operating fundamentals. Recently, scholars have identified that there is an impact of the nature of the industry on measurements of the earnings quality of entities.

As discussed in the literature review, previous studies that investigated earnings quality and stock returns have considered the whole share market, disregarding the nature of the industry involved. However, the findings of prior studies indicate that earnings management varies across industries. Therefore, a measure applicable for one industry might not be applicable for another industry to accurately gauge the earnings quality. At the same time, prior studies have not tested the accrual approach, real earnings management approach and other measurements using the same data set. Such a test could be useful in identifying the compatibilities of the various earnings management measurements for a given context. Apart from testing all the proxy measures using a single data set, a gap exists in investigations of the relationship between earnings quality measured by real earnings management and stock returns in the manufacturing sector. Since there has been no prior studies carried out in the context of Sri Lanka on the earnings quality phenomenon, the present study attempts to add empirical evidence to this aspect as well. Considering the fact that earnings quality of different industries differs, the present study uses the data of listed manufacturing firms on the Colombo Stock Exchange (CSE) during 2010-2015.

\section{Methodology}

According to Fama (1991), the share price provides an accurate signal for investors to allocate their resources to entities. Following scholars whose studies are based on the efficient market theory, Tumurkhuu and Wang (2010) defined the term efficiency as informational efficiency, which deals with the association between information and securities prices. Thus, it could be presumed that there is a relationship between information and stock returns.

The seminal study done by Ball and Brown (1968) to establish the relationship between earnings and stock returns, argues that using an analytical approach that deals with income only has little meaning, since it is difficult to accommodate 
everything in the real scenario of the analysis. A theoretical relationship exists between earnings and stock returns, which can be explained through the efficient market theory (Fama, 1970) and the random walk concept which is the underlying concept for earlier theories (Samuelson, 1965). By studying the common valuation techniques used in finance such as the residual income approach, the relationship between earnings and stock returns can be further strengthened. Moreover, the argument put forward by Ball and Brown (1968) also supports the same relationship. Finally, the quality of earnings is one of the concerns of the investors, and becomes important in building the relationship between earnings quality and stock returns, since a higher quality of earnings provides a positive signal to investors.

Further, as cited in Ou and Penman (1989), numerous scholars have concluded that stock prices lead to accounting earnings with a time lag (Beaver, Lambert, \& Morse, 1980; Beaver, Lambert, \& Ryan, 1987; Collins, Kothari, \& Rayburn 1987; Freeman, 1987). Based on these arguments, supportive evidence is available to establish a relationship between lagged earnings and stock returns.

The dependent variable of the study is stock returns of the individual firms $\left(R_{i t}\right)$ which is calculated by taking the quarterly closing price difference divided by the previous quarter closing price of the selected companies (Chan et al., 2006; Penman \& Zhang , 2002).

$$
R_{i t}=\frac{\text { (Closing price } \left._{i t}-\text { Closing price }_{i t-1}\right)}{\text { Closing price }_{i t-1}}
$$

The independent variable of the study, earnings quality, is measured through ten main measures/proxies that represent the accrual, real and other approaches (see Table 1 for details).

Table 1: Measurements/Proxies of Earnings Quality

\begin{tabular}{lll}
\hline \multicolumn{1}{c}{$\begin{array}{c}\text { Proxies of } \\
\text { Earnings Quality }\end{array}$} & \multicolumn{1}{c}{ Definition } \\
\hline 1 & $\begin{array}{l}\text { Hribar and Collins's (2002) } \\
\text { ratio (HCR) }\end{array}$ & $\begin{array}{l}\text { The difference between earnings and } \\
\text { cash flow from operating activities. }\end{array}$ \\
2 & $\begin{array}{l}\text { Dechow and Dichev's (2002) } \\
\text { ratio (DDR) }\end{array}$ & $\begin{array}{l}\text { Change in working capital calculated by } \\
\text { taking the difference between current } \\
\text { assets and current liabilities. }\end{array}$ \\
\hline
\end{tabular}




\begin{tabular}{|c|c|c|}
\hline & $\begin{array}{c}\text { Proxies of } \\
\text { Earnings Quality }\end{array}$ & Definition \\
\hline 3 & $\begin{array}{l}\text { Penman's (2001) approach } \\
\text { (PENR) cited in Penman and } \\
\text { Zhang (2002) }\end{array}$ & $\begin{array}{l}\text { Cash flow from operations divided by } \\
\text { net income. }\end{array}$ \\
\hline 4 & $\begin{array}{l}\text { Barton and Simko’s (2002) } \\
\text { ratio } \\
\text { (BSR) }\end{array}$ & $\begin{array}{l}\text { Ratio of the beginning balance of } \\
\text { quarterly net operating assets (NOA) } \\
\text { relative to sales. }\end{array}$ \\
\hline 5 & $\begin{array}{l}\text { Lyimo's (2014) ratio } \\
\text { (LMR) }\end{array}$ & $\begin{array}{l}\text { Difference between earnings and cash } \\
\text { flow divided by the average assets. }\end{array}$ \\
\hline 6 & $\begin{array}{l}\text { Abnormal cash flows from } \\
\text { operating activities } \\
\text { (AB_CFO) }\end{array}$ & $\begin{array}{l}\text { Difference between the normal cash flow } \\
\text { and the firm specific cash flow. }\end{array}$ \\
\hline 7 & $\begin{array}{l}\text { Abnormal discretionary } \\
\text { expenses (AB_DISEX) }\end{array}$ & $\begin{array}{l}\text { Difference between the normal expenses } \\
\text { and the firm specific expenses. }\end{array}$ \\
\hline 8 & $\begin{array}{l}\text { Abnormal production cost } \\
\left(\mathrm{AB} \_ \text {PROD) }\right.\end{array}$ & $\begin{array}{l}\text { Difference between the normal } \\
\text { production cost and the firm specific } \\
\text { production cost. }\end{array}$ \\
\hline 9 & $\begin{array}{l}\text { As a combination of } \\
\left(\mathrm{AB} \_\mathrm{CFO}\right),\left(\mathrm{AB} \_\mathrm{DISEX}\right) \text { and } \\
\left(\mathrm{AB} \_ \text {PROD) }\right.\end{array}$ & Same as above \\
\hline 10 & Cash flow of the entity & $\begin{array}{l}\text { The cash flow of an entity is the net cash } \\
\text { flow for the year (TCF) as it appears in } \\
\text { the quarterly financial statements of the } \\
\text { entity. However the net cash flow from } \\
\text { operating activities (CFO), net cash flow } \\
\text { from investing activities (CFI) and net } \\
\text { cash flow from financing (CFF) } \\
\text { activities are also considered. }\end{array}$ \\
\hline
\end{tabular}

Following Roychowdhury (2006), the study calculated normal levels of operating cash flow, production cost and discretionary expenses to compare with actual firm values that take abnormal values. When taking normal levels of operating cash flow, production cost and discretionary expenses, cross-sectional regressions are used for each quarter of the sample period. In addition to the Roychowdhury (2006) approach, the same normal levels are calculated for the whole sample period to see whether there is any discrepancy in the normal levels of operating cash flow, production cost and discretionary expenses compared to their quarterly values. The regression performed to capture the normal cash flow from operations is as follows. 
$\frac{\mathrm{CFO}_{i t}}{\mathrm{~A}_{i t-1}}=\beta_{0}+\beta_{1}\left(\frac{1}{\mathrm{~A}_{i t-1}}\right)+\beta_{2}\left(\frac{\text { Sales }_{i t}}{\mathrm{~A}_{i t-1}}\right)+\beta_{3}\left(\frac{\Delta \text { Sales }_{i t}}{\mathrm{~A}_{i t-1}}\right)+\varepsilon_{i t}$

where,

$\mathrm{CFO}_{i t}-$ Cash flow from operation

$\mathrm{A}_{i t-1} \quad$ - Total assets

Sales $_{i t}-$ Sales

$\Delta$ Sales $_{i t}$ - Difference between sales of the present quarter and the previous quarter. $\varepsilon_{i t}-$ Error term

The model to capture the normal discretionary expenses of the selected firms for the study is presented below.

$\frac{\operatorname{DISEXP}_{i t}}{\mathrm{~A}_{i t-1}}=\beta_{0}+\beta_{1}\left(\frac{1}{\mathrm{~A}_{i t-1}}\right)+\beta_{2}\left(\frac{\text { Sales }_{i t-1}}{\mathrm{~A}_{i t-1}}\right)+\varepsilon_{i t}$

where,

DISEXP $_{i t}-$ The sum of research and development expenses and selling, general and administrative expenses, and all other variables are as previously defined in equation 1 above.

The model that illustrates the normal production cost of the selected firms for the study is given below.

$\frac{\text { PROD }_{i t}}{\mathrm{~A}_{i t-1}}=\beta_{0}+\beta_{1}\left(\frac{1}{\mathrm{~A}_{i t-1}}\right)+\beta_{2}\left(\frac{\text { Sales }_{i t}}{\mathrm{~A}_{i t-1}}\right)+\beta_{3}\left(\frac{\Delta \text { Sales }_{i t}}{\mathrm{~A}_{i t-1}}\right)+\beta_{4}\left(\frac{\Delta \text { Sales }_{i t-1}}{\mathrm{~A}_{i t-1}}\right)+\varepsilon_{i t}$

where,

$\mathrm{PROD}_{i t}$ - The sum of the cost of goods sold and the change in inventory

$\Delta$ Sales $_{i t-1}-$ Sales of $i^{\text {th }}$ Company in quarter $t$ - 1 less sales of $i^{\text {th }}$ Company in quarter $t$ 2 ; all other variables are as defined in previous equations.

The cost of goods sold and the change in inventory are calculated as below.

$\frac{\operatorname{COGS}_{i t}}{\mathrm{~A}_{i t-1}}=\beta_{0}+\beta_{1}\left(\frac{1}{\mathrm{~A}_{i t-1}}\right)+\beta_{2}\left(\frac{\text { Sales }_{\mathrm{it}}}{\mathrm{A}_{i t-1}}\right)+\varepsilon_{i t}$

where,

COGS $_{i t}$ - the sum of the cost of goods sold in the $i^{\text {th }}$ Company in quarter $t$, and all other variables are as previously defined. 
$\frac{\Delta \mathrm{INV}_{i t}}{\mathrm{~A}_{i t-1}}=\beta_{0}+\beta_{1}\left(\frac{1}{\mathrm{~A}_{i t-1}}\right)+\beta_{2}\left(\frac{\Delta \text { Sales }_{i t}}{\mathrm{~A}_{i t-1}}\right)+\beta_{3}\left(\frac{\Delta \text { Sales }_{i t-1}}{\mathrm{~A}_{i t-1}}\right)+\varepsilon_{i t}$

where,

$\Delta \mathrm{INV}_{i t}-$ Inventory of $i^{\text {th }}$ Company in quarter $t$ less inventory of $i^{\text {th }}$ Company in quarter $t$ - 1 , and all other variables are as previously defined.

Previous scholars have used firm size as a controlling variable since it can have an impact on the relationship between earnings quality and stock returns (see Burgstahler \& Dichev, 1997; Chan et al., 2006; Roychowdhury, 2006). Yamchi et al. (2013) found that firm size does not associate with earnings quality. However, Dechow et al. (2010) reported that firm size is positively associated with earnings quality. Therefore, the present study includes firm size as a controlling variable in the estimation of the relationship between earnings quality and stock returns. The proxy measure used to measure the firm size of the selected firms for this study is the logarithm of total assets, because total assets have a nonlinear relationship with stock returns.

Based on the above discussion, the following hypothesis is developed.

$\mathrm{H}_{1}$ : Earnings quality has a positive impact on stock returns of listed manufacturing firms in Sri Lanka.

For the purpose of analysis, quarterly data of manufacturing companies listed on the CSE during the period of 2010 to 2015 have been used in the study. According to previous findings of Abdelghany (2005), Lyimo (2014) and Wasiuzzaman et al. (2015) earnings management varies across different industries. Therefore, a measure/proxy applicable for one industry might not applicable for another industry when measuring earnings quality. The manufacturing sector is one of the sectors where scholars highlight the importance of investigating the earnings quality phenomenon (Halabi \& Abbadi, 2014; Burgstahler \& Dichev, 1997; Roychowdhury, 2006).

\section{Empirical Results}

According to summary statistics (not tabulated) of the data used in the study, the average earnings and operating cash flow of the listed manufacturing sector companies amounted to Rs. 75.09 million and Rs.145.38 million, respectively. The maximum earnings were recorded by Dipped Products PLC for the second quarter 
of 2012, and Royal Ceramics Lanka PLC is the largest assets holder for the fourth quarter of 2015. The mean HCR value of the listed manufacturing sector is Rs. 100.14 million and the maximum value is Rs. 1,893.72 million. The average sales of the industry are Rs. 1,192.511 million and the highest sales of Rs. 9,108.6 million was recorded by Tokyo Cement Lanka PLC for the fourth quarter of 2013.The highest AB_CFO and AB_DISEXP were recorded by Tokyo Cement Co Lanka PLC for the fourth quarter ended 2014 and the highest AB_PROD was recorded by Dipped Products PLC for the first quarter ended 2013. To get an initial understanding of the relationship between earnings quality, measured through different measures/proxies and stock returns, the results are summarised in Table 2.

Table 2: Correlation between Earnings Quality and Stock Returns

\begin{tabular}{lccccccccccccc}
\hline & HCR & DDR & PENR & BSR LMR & $\begin{array}{c}\text { AB } \\
\text { CFO }^{-}\end{array}$ & $\begin{array}{c}\mathbf{A B}_{-} \\
\text {DISEXP }\end{array}$ & $\begin{array}{c}\mathbf{A B}_{-} \\
\text {PROD }\end{array}$ & CFO & CFI CFF & TCF \\
\hline $\begin{array}{l}\text { Stock } \\
\text { returns }\end{array}$ & 0.00 & 0.02 & 0.01 & 0.00 & 0.01 & -0.01 & -0.01 & -0.02 & 0.00 & -0.01 & 0.02 & -0.01 \\
$\boldsymbol{p}$ value & 0.91 & 0.62 & 0.87 & 0.93 & 0.75 & 0.80 & 0.74 & 0.66 & 0.78 & 0.68 & 0.87 & 0.94 \\
\hline $\boldsymbol{n}=624$. & & & & & & & & & & & &
\end{tabular}

According to Table 2 it can be seen that earnings quality of selected firms for the study measured through different measures/proxies summarised in Table 1 do not have a significant correlation with stock returns. To affirm the above observation adequately, the study carried out a regression analysis.

Before estimating the regression models presented earlier, the study performed the Levin, Lin and Chu test; the Im, Pesaran test; the Shin W-stat ADF test; the Fisher Chi-square test; and the PP - Fisher Chi-square test to check the stationarity of the data. From the results of the above tests, it can be seen that all variables are stationary at this level, except abnormal discretionary expenses (AB_DISEXP and ABT_DISEX). However, AB_DISEXP and ABT_DISEX are stationary at the first difference.

To ensure linearity of the relationship between the independent variables and the dependent variables of the study, the values of the independent variables and the control variables were converted into log values. After the conversion, correlations among independent variables were obtained to test the existence of multicollinearity issues. Correlation coefficients of the independent variable combinations ranged between 0.03 (LOGABPROD and LOGABDISEXP) and 0.22 (LOGABPROD and LOGABCFO). Based on the above weak correlations, the non-existence of 
multicollinearity issues among independent variables used in the present study is confirmed.

Thereafter, the regression estimates using the regression models of the study were drawn through the most appropriate panel data models (i.e. fixed effects and random effects). Table 3 allocates a panel each to present the regression results of the impact of earnings quality on stock returns of selected firms, measured through the measurements in Table 1. Whether the fixed effects model or the random effects model is more appropriate for the respective estimation was decided by using the Hauseman Specification Test. The White (1980) heteroscedasticityconsistent covariance matrix estimator was used to rectify possible heteroscedasticity issues in the models. Table 3 also presents evidence on the delayed response of earnings qualities of selected firms on contemporaneous stock returns.

Table 3: Regression Estimates of the Impact of Earnings Quality on Stock Returns

\begin{tabular}{llllll}
\hline Quarter & \multicolumn{2}{c}{$t$} & \multicolumn{2}{c}{$t-2$} & \multicolumn{2}{c}{$t-3$} \\
& Coeffi. & $p$ value & Coeffi. $\quad p$ value & Coeffi. $p$ value Coeffi. $p$ value \\
\hline
\end{tabular}

Panel A: Earnings quality based on HCR

$\begin{array}{lrlllllll}\text { LOGHCR } & 0.042 & 0.905 & -0.029 & 0.072 & -0.097 & 0.240 & -0.014 & 0.866 \\ \text { Intercept } & -0.175 & 0.948 & 0.279 & 0.653 & 0.796 & 0.209 & 0.157 & 0.809 \\ \text { F statistic } & 0.014 & & 0.132 & & 1.422 & & 0.029 & \\ p \text { value } & 0.905 & & 0.716 & & 0.233 & & 0.863 & \end{array}$

Panel B: Earnings quality based on DDR

$\begin{array}{lrlllllll}\text { LOGDDR } & 0.033 & 0.840 & 0.044 & 0.270 & 0.002 & 0.962 & -0.016 & 0.720 \\ \text { Intercept } & -0.080 & 0.940 & -0.250 & 0.371 & 0.036 & 0.910 & 0.159 & 0.610 \\ \text { F statistic } & 0.123 & & 0.011 & & 0.367 & & 0.475 & \\ p \text { value } & 0.840 & & 0.260 & & 0.960 & & 0.710 & \end{array}$

Panel C: Earnings quality based on PENR

$\begin{array}{lrrrrrrrr}\text { LOGPENR } & 0.481 & 0.257 & 0.107 & 0.272 & 0.080 & 0.420 & -0.102 & 0.310 \\ \text { Intercept } & -0.738 & 0.670 & -0.533 & 0.321 & -0.393 & 0.476 & 0.611 & 0.271 \\ \text { F statistic } & 1.288 & & 1.245 & & 0.671 & & 1.067 & \\ & p \text { value } & 0.256 & & 0.264 & & 0.412 & & 0.301\end{array}$




\begin{tabular}{lcccccccc}
\hline Quarter & \multicolumn{2}{c}{$\boldsymbol{t}$} & \multicolumn{2}{c}{$\boldsymbol{t}-\mathbf{1}$} & \multicolumn{2}{c}{$\boldsymbol{t}-\mathbf{2}$} & \multicolumn{2}{c}{$\boldsymbol{t}-\mathbf{3}$} \\
& Coeffi. & $\boldsymbol{p}$ value & Coeffi. & $\boldsymbol{p}$ value & Coeffi. & $\boldsymbol{p}$ value & Coeffi. & $\boldsymbol{p}$ value \\
\hline Panel D: Earnings quality based on BSR & & & & & & \\
LOGBSR & 0.215 & 0.105 & 0.006 & 0.743 & -0.013 & 0.488 & 0.001 & 0.961 \\
Intercept & -0.126 & 0.490 & 0.048 & 0.084 & 0.070 & 0.015 & 0.046 & 0.117 \\
F statistic & 0.997 & & 0.110 & & 0.494 & & 0.002 & \\
$p$ value & 0.468 & & 0.739 & & 0.482 & & 0.960 &
\end{tabular}

Panel E: Earnings quality based on LMR

$\begin{array}{lrlllllll}\text { LOGLMR } & 0.191 & 0.734 & 0.169 & 0.203 & -0.119 & 0.391 & -0.315 & 0.030^{*} \\ \text { Intercept } & 0.149 & 0.007 & 0.060 & 0.000 & 0.050 & 0.000 & 0.041 & 0.000^{* *} \\ \text { F statistic } & 0.116 & & 1.677 & & 0.761 & & 5.186 & \\ p \text { value } & 0.734 & & 0.196 & & 0.384 & & 0.023^{*} & \\ \text { Adjusted } R^{2} & & & & & & & 0.76 \% & \end{array}$

Panel F: Earnings quality based on ABCFO

$\begin{array}{lrlrrrrrr}\text { LOGABCFO } & -0.011 & 0.959 & -0.009 & 0.853 & 0.023 & 0.642 & 0.027 & 0.595 \\ \text { Intercept } & 0.070 & 0.962 & 0.348 & 0.727 & -0.114 & 0.749 & -0.146 & 0.687 \\ \text { F statistic } & 0.003 & & 0.035 & & 0.222 & & 0.029 & \\ p \text { value } & 0.959 & & 0.851 & & 0.637 & & 0.589 & \end{array}$

Panel G: Earnings quality based on ABDISEXP

$\begin{array}{lrrrrrrrr}\text { LOGABDISEXP } & -0.107 & 0.702 & 0.190 & 0.000^{* *} & -0.034 & 0.597 & -0.116 & 0.072 \\ \text { Intercept } & 0.849 & 0.645 & -1.190 & 0.000^{* *} & 0.274 & 0.516 & 0.808 & 0.057 \\ \text { F statistic } & 0.147 & & 9.155 & & 0.289 & & 3.356 & \\ p \text { value } & 0.702 & & 0.000^{* *} & & 0.591 & & 0.068 & \end{array}$

Adjusted $\mathrm{R}^{2}$

0.013

Panel H: Earnings quality based on ABPROD

$\begin{array}{lrlllllll}\text { LOGABPROD } & -0.826 & 0.499 & -0.021 & 0.443 & -0.033 & 0.268 & -0.154 & 0.103 \\ \text { Intercept } & 0.753 & 0.403 & 0.217 & 0.298 & 0.296 & 0.180 & 1.181 & 0.089 \\ \text { F statistic } & 0.458 & & 0.605 & & 1.257 & & 0.349 & \\ p \text { value } & 0.498 & & 0.436 & & 0.262 & & 0.998 & \end{array}$




\begin{tabular}{lccccccccc}
\hline Quarter & \multicolumn{2}{c}{$\boldsymbol{t}$} & \multicolumn{2}{c}{$\boldsymbol{t}-\mathbf{1}$} & \multicolumn{2}{c}{$\boldsymbol{t}-\mathbf{2}$} & \multicolumn{2}{c}{$\boldsymbol{t}-\mathbf{3}$} \\
& Coeffi. & $\boldsymbol{p}$ value & Coeffi. & $\boldsymbol{p}$ value & Coeffi. & $\boldsymbol{p}$ value & Coeffi. & $\boldsymbol{p}$ value \\
\hline \multicolumn{2}{l}{ Panel I: Earnings quality based on ABCFO, ABDISEXP and ABPROD } & & & \\
LOGABCFO & 0.029 & 0.891 & -0.003 & 0.940 & 0.031 & 0.543 & 0.033 & 0.517 \\
& & & & & & & & \\
LOFABDISEXP & -0.091 & 0.746 & 0.196 & $0.000^{* *}$ & -0.028 & 0.662 & -0.112 & 0.083 \\
LOGABPROD & -0.080 & 0.518 & -0.029 & 0.302 & -0.034 & 0.255 & -0.025 & 0.409 \\
Intercept & 1.132 & 0.642 & -0.471 & 0.676 & 0.271 & 0.631 & 0.734 & 0.201 \\
F statistic & 0.190 & & 3.421 & & 0.626 & & 1.469 & \\
$p$ value & 0.902 & & 0.017 & & 0.597 & & 0.221 & \\
& & & & & & & & \\
\hline
\end{tabular}

Notes: $\quad * \mathrm{p}<0.05 ; * * \mathrm{p}<0.01$ and reported $\mathrm{t}$-values are based on White $(1980)$ standard errors. $n=624$

As the final proxy, the study employed TCF to measure the impact of TCF on stock returns, and the study also considered CFO, CFI and CFF as the measures of earnings quality. The results of the analysis are presented in Table 4.

Empirical evidence in Tables 3 and 4 was used to test $\mathrm{H}_{1}$, earnings quality has a positive impact on stock returns of listed manufacturing firms in Sri Lanka, used in the study. The evidence is also useful to identify whether all measures/proxies used to quantify earnings quality give the same results. Accordingly, it was found that earnings quality obtained through each measure does not have a statistically significant positive relationship with stock returns of the selected firms, and thus, $\mathrm{H}_{1}$ was rejected. However, the third lag of $\log$ LMR provides evidence for a positive impact of earnings quality on stock returns.

According to the results of the analysis there is no impact from earnings quality on stock returns of the selected firms. The lag analysis on earnings also does not provide evidence on the impact of earnings on stock returns up to the third lag. According to the results, the sizes of the companies measured by their log assets do not have any influence on the impact of earnings on stock returns. Therefore, the company size is not a determining factor when investigating the impact of earnings on stock returns. 
Table 4: The Impact of Log Cash Flow on Stock Returns

\begin{tabular}{|c|c|c|c|c|c|c|c|c|}
\hline \multirow[t]{2}{*}{ Quarter } & \multicolumn{2}{|c|}{$t$} & \multicolumn{2}{|c|}{$t-1$} & \multicolumn{2}{|c|}{$t-2$} & \multicolumn{2}{|c|}{$t-3$} \\
\hline & Coeffi. & $p$ value & Coeffi. & $p$ value & Coeffi. & $p$ value & Coeffi. & $p$ value \\
\hline LOGTCF & 0.00001 & 0.9414 & -0.00001 & 0.6116 & 0.00000 & 0.8203 & 0.04167 & 0.5193 \\
\hline Intercept & 0.14460 & 0.0072 & 0.05764 & 0.0000 & 0.05168 & 0.0001 & -2.26005 & 0.5801 \\
\hline F statistic & 0.00542 & & 0.26633 & & 0.06374 & & 0.05334 & \\
\hline$p$ value & 0.94137 & & 0.60600 & & 0.80077 & & 0.81742 & \\
\hline LOGCFO & -0.03645 & 0.8735 & -0.05390 & & -0.03851 & 0.4748 & 0.07120 & 0.1974 \\
\hline Intercept & 0.40649 & 0.8048 & 0.44404 & & 0.32820 & 0.3962 & -0.46326 & 0.2425 \\
\hline F statistic & 0.02544 & & 1.06660 & & 0.58571 & & 1.72215 & \\
\hline$p$ value & 0.87332 & & 0.30213 & & 0.94926 & & 0.18997 & \\
\hline LOGCFI & 0.01300 & 0.2426 & -0.00080 & & 0.00248 & 0.7734 & -0.04965 & $0.0008^{*}$ \\
\hline Intercept & 0.00556 & 0.8835 & 0.08142 & & 0.04816 & 0.1069 & 0.10440 & $0.0050 * *$ \\
\hline F statistic & 1.48000 & & 0.77691 & & 0.58571 & & 1.63547 & \\
\hline$p$ value & 0.22511 & & 0.37965 & & 0.94926 & & $0.04982 *$ & \\
\hline Adj. $R^{2}$ & & & & & & & $10.40 \%$ & \\
\hline LOGCFF & -0.03490 & $0.031 *$ & -0.00769 & & -0.00025 & 0.9834 & -0.00331 & 0.7912 \\
\hline Intercept & 0.19928 & $0.004 * *$ & 0.08172 & & 0.05072 & 0.3282 & 0.04990 & 0.3471 \\
\hline F statistic & 4.82000 & & 0.45695 & & 0.00043 & & 0.07580 & \\
\hline$p$ value & $0.02894 *$ & & 0.49967 & & 0.9834 & & 0.78332 & \\
\hline Adj. $R^{2}$ & $1.40 \%$ & & & & & & & \\
\hline
\end{tabular}

Notes: LOGCFI, $t-2$ and $t-3$ estimates are based on Fixed Effects Models. All other estimates are based on Random Effects Models.

$* \mathrm{p}<5 ; * * \mathrm{p}<1$, and reported $t$-values are based on White (1980) standard errors. $n=624$

\section{Conclusion}

According to the empirical evidence presented in the previous section, earnings quality of the selected firms for this study does not significantly impact stock returns. Thus $\mathrm{H}_{1}$, which hypothesised that earnings quality has a significant positive impact on stock return of listed manufacturing firms in Sri Lanka, could not be established. Subsequently, it was concluded that earnings quality of the selected firms was not a significant determinant of their stock returns. This conclusion has been reached despite the fact that earnings quality is measured through all the 
available measurements in the earnings quality literature. The conclusion, however, indicates that the application of two different types (accrual based and real earnings) of earnings quality measurements return relatively identical results in terms of the impact of earnings quality on stock returns. Moreover, the evidence on the delayed response of earnings quality of the selected firms on stock returns is also inconclusive.

The above findings imply that the investors of the firms selected for this study do not trust the information they receive on earnings quality, and do not consider earnings quality information when making their contemporaneous or future investment decisions. Based on the findings, a lack of investor ability to analyse financial statements may be presumed, or it might be surmised that investors may not possess sufficient knowledge on earnings quality. Although the efficient market hypothesis and the signalling theory both maintain that all publicly available information is reflected in stock returns, it appears that investors in the selected firms do not utilise earnings quality information, or they use other information when allocating their resources. Therefore, the present study provides evidence on a context where the theoretical expectations of the above theories do not hold. Further, the results of the present study are not in line with the findings of Chan et al., (2006), Allen, Larson, and Sloan (2011) and Sloan (1996) who systematically showed a significant relationship between accruals and future earnings as well as a positive relationship between earnings quality and stock returns. According to Osei (2002) a conclusive relationship between earnings quality and stock returns does not appear in emerging markets. Possible reasons for the contrasting findings in the present study compared to the theoretical expectations of the efficient market hypothesis and the signalling theory could be the existence of a relatively large number of poorly informed and unsophisticated investors; low liquidity levels of the firms selected for the study; weak legal, regulatory and institutional frameworks; and operational bottlenecks.

Greenberg, Johnson, and Ramesh (1986) empirically examined and suggested that earnings are the best predictors of future cash flows rather than current cash flows. At the same time, Dechow, Kothari, and Watts (1998) also concluded that current earnings are a superior predictor of future cash flows rather than current operating cash flows. However, the findings of the present study contradict these findings, as the current study found that there is no impact from earnings and lag earnings on stock returns. Further, the current researchers' findings are not in line with Menike and Prabath (2014), Ball and Brown (1968) and Dechow (1994) who 
suggested that in an entity, earnings are a superior predictor than cash flow. However, the study provides supportive evidence for the findings of Abdelghany (2005), Lyimo (2014) and Wasiuzzaman et al., (2015). These studies have confirmed that a single proxy to measure the earnings quality of the whole market is not suitable, since it leads to different opinions on earnings qualities of firms.

This study is not without its limitations. It could not consider all proxy measurements to measure the quality of the earnings, since data of some variables could not be garnered from publicly available information. Furthermore, the findings of this study are based on the data culled from the manufacturing sector of Sri Lanka. Therefore the application of the findings in making earnings quality decisions beyond the context of the manufacturing sector of Sri Lanka needs caution, as contextual differences would certainly impact earnings management practices in such contexts. Hence, future studies could compare the impact of earnings quality on stock returns of manufacturing sector firms in different countries, and in other industries from different settings. The present study reports that investors in manufacturing industries in Sri Lanka do not consider, to any great extent, earnings quality or earnings in their investment decision making. Therefore, further studies are required to find out the determinants of stock returns in Sri Lankan industries listed in the manufacturing sector.

\section{References}

Abdelghany, K. E. (2005). Measuring the quality of earnings. Managerial Auditing Journal, 20(9), 1001-1015.

Allen, E., Larson, C., \& Sloan, R. G. (2011). Accrual reversals, earnings and stock returns. Berkeley: School of Business, University of California.

Ball, R., \& Brown P. (1968). An empirical evaluation of accounting income numbers. Journal of Accounting Research, 6(2), 159-178.

Barton, J., \& Simko, P. J. (2002). The balance sheet as an earnings management constraint. The Accounting Review, 77, 1-27.

Basilico, E. (2014). The quality of earnings, governance and future stock returns in Europe: An empirical study. Retrieved on June 15, 2017, from http://www.1.inisg.ch/www/edis.nsf.

Bodie, Z., Kane, A., \& Marcus, A. (2002). Investments (6 ${ }^{\text {th }}$ ed.). New York: McGraw Hill Higher Education.

Braam, G., Nandy, M., Weitzel, U., \& Lodh, S. (2015). Accrual based and real earnings management and political connections. International Journal of Accounting. 50(2), 111-141. 
Burgstahler D., \& Dichev, I. (1997). Earnings management to avoid earnings decreases and losses. Journal of Accounting and Economics, 24(1), 99-126.

Chan, K., Chan, L., Jegadeesh, N., \& Lakonishok, J., (2006). Earnings quality and stock returns. Journal of Business, 79, 1041-1082.

Cohen, D., Dey, A., \& Lys, T. (2008). Real and accruals based earnings management in the pre- and post-Sarbanes-Oxley periods. The Accounting Review, 83(3), 757-787.

Dechow, P. M. (1994). Accounting earnings and cash flows as measures of firm performance: The role of accounting accruals. Journal of Accounting and Economics, 18(1) 3-42.

Dechow, P. M., \& Dichev, I. D. (2002). The quality of accruals and earnings: The role of accrual estimation errors. The Accounting Review, 77(1), 35-59.

Dechow, P. M., Ge, W., Schrand C. (2010), Understanding earnings quality: A review of the proxies, their determinants and their consequences. Journal of Accounting and Economics, 50(2-3), 344-401.

Dechow, P. M., Kothari, S. P., \& Watts, R. L. (1998). The relation between earnings and cash flows. Journal of Accounting and Economics, 25(2), 133-168.

Dechow, P. M., Sloan, R., Sweeney, A. (1995). Detecting earnings management. The Accounting Review, 70(2), 193-225.

Ewert, R., \& Wagenhofer, A. (2005). Economic effects of tightening accounting standards to restrict earnings management. The Accountings Review, 80(4), 1101-1124.

Fama, E. (1970). Efficient capital markets: A review of theory and empirical work. The Journal of Finance, 25(2), 383-417.

Fama, E. (1991). Efficient capital markets II. Journal of Finance, 46(5), 1575-1671.

Greenberg, R., Johnson, G., Ramesh, K., (1986). Earnings versus cash flow as a predictor of future cash flow measures. Journal of Accounting, Auditing and Finance, 1(4), 266-277.

Gunny, K. A. (2010). The relation between earnings management using real activities manipulation and future performance: Evidence from meeting earnings benchmarks. University of Colorado Contemporary Accounting Research, 27(3), 855-888.

Guo, J., Huang P., Zhang, Y., \& Zhou, N. (2014). Foreign ownership and real earnings management: Evidence from Japan. Retrieved on 20 June 2017, from http://www.af.polyu.edu.hk.

Halabi, N. B. A., \& Abbadi, H. I. A. (2014). The impact of applying financial performance indicators on earnings management in manufacturing companies. European Journal of Business and Management, 6(24), 80-86. 
Healy, P. M. (1985). The effect of bonus schemes on accounting decisions, Journal of Accounting and Economics, 7, 85-107.

Healy, P. M., \& Wahlen, J. M. (1999). A review of the earnings management literature and its implications for standard setting. Accounting Horizons, 13(4), 365-383.

Hribar, P., \& Collins, D. W. (2002). Errors in estimating accruals: Implications for empirical research. Journal of Accounting Research, 40(1), 105-134.

Jones, J. (1991). Earnings management during import relief investigations. Journal of Accounting Research, 29(2), 193-228.

Kamarudin, K. A., \& Ismail, W. A. W. (2014). Earnings quality construct and measures in empirical accounting studies. International Conference on Governance \& Strategic Management (ICGSM), Retrieved on 21 June, 2017, from www.sciencedirect.com.

Kighir, A., Omar, N., \& Mohamed, N. (2014). Earnings management detection modelling: A methodological review. World Journal of Social Sciences, 4(1), $18-32$.

Leuz, C., Nanda, D., \& Wysocki, P. (2003). Earnings management and investor protection: an international comparison, Journal of financial Economics, 69(3), 505-527.

Lyimo, G. D. (2014). Assessing the measures of quality of earnings: Evidence from India. European Journal of Accounting Auditing and Finance Research, 2(6), 17-28.

Menike, M. G. P. D., \& Prabath, U. S. (2014). The impact of accounting variables on stock price: Evidence from the Colombo Stock Exchange, Sri Lanka. International Journal of Business and Management, 9(5), 125-137.

Meyer, C. (2007). Shareholder value accounting the value relevance of financial statement data and the determinants of accounting method choices. Retrieved on 10 June, 2017 from http://www.research-projects.uzh.ch.

Noronha, C., Zeng Y., \& Vinten, G. (2008). Earnings management in China: an exploratory study. Managerial Auditing Journal, 23(4), 367-385.

Osei, K. A. (2002). The investor profile of the Ghana Stock Market. Journal of Management Studies, 17, 95-114.

Ou, J. A., \& Penman, S. H. (1989). Accounting measurement, price-earnings ratio and the information content of security prices. Journal of Accounting Research, 27, 111-144.

Peasnell, K. V., Pope, P. F., \& Young, S. (2000). Detecting earnings management using cross sectional abnormal accrual models. Accounting and Business Research, 30(4), 313-326. 
Penman, S. H., \& Zhang, X. J. (2002). Accounting conservatism, the quality of earnings and stock returns. The Accounting Review, 77(2), 237-264.

Revsine, L., Collins, D., Johnson, W. (2002). Financial reporting and analysis (2 ${ }^{\text {nd }}$ ed.) New Jersey: Prentice Hall.

Richardson, S. A., Sloan, R. G., Soliman, M. T., \& Tuna, A. I. (2005). Accrual reliability, earnings persistence and stock prices. Journal of Accounting and Economics, 39, 437-485.

Roychowdhury, S. (2006). Earnings management through real activities manipulation. Journal of Accounting and Economics, 42, 335-370.

Samuelson, P. A. (1965). Proof that properly anticipated prices fluctuate randomly. Industrial Management Review, 6, 41-49.

Schipper, K. (1989). Commentary on earnings management. Accounting Horizons, 3(4), 91-102.

Sloan, R. (1996). Do stock prices fully reflect information in accruals and cash flows about future earnings? The Accounting Review, 71(3), 289-315.

Tumurkhuu, T., \& Wang, X. (2010). The relationship between the profit warning and stock returns: Empirical evidence in EU markets, Umea School of Business. Retrieved on 20 June, 2017, from http://umu.diva-portal.org.

Wasiuzzaman, S., Sahafzadeh, I., \& Nejad, N. R. (2015). Prospect theory, industry characteristics and earnings management: A study of Malaysian industries. Review of Accounting and Finance, 14(3), 324-347.

White, B. (1980). A heteroskedasticity-consistent covariance matrix estimator and a direct test for heteroskedasticity. Econometrica, 5(2), 171-180.

Yamchi, N. H., Salteh, H. M., \& Nahandi, Y. B. (2013). Earnings quality and stock returns. Trends in Social Science, 8(1), 61-71. 